\title{
Model Deskriptif Pola Penggunaan Lahan
}

Nurfatimah, Universitas Islam Negeri Alauddin Makassar nurfatimah.nurfatimah91@gmail.com

Susunan Penggunaan lahan pada suatu wilayah akan membentuk pola yang berbeda - beda antara satu wilayah dengan wilayah lainnya. Menurut Bintarto (1977:56), adanya perbedaan luas daerah kota, unsur topografi, faktor social, faktor budaya, faktor politik, dan faktor ekonomi. Pembahasan pola penggunaan lahan dan faktor - faktor yang mempengaruhi terbentuknya pola tersebut terbagi menjadi :

1. Pola penggunaan lahan di kawasan perkotaan

2. Pola penggunaan lahan di kawasan perdesaan

Kawasan perkotaan adalah wilayah yang mempunyai kegiatan utama bukan pertanian dengan susunan fungsi kawasan sebagai tempat permukiman, perkotaan, pemusatan dan distribusi pelayanan jasa pemerintahan, pelayanan social, dan kegiatan ekonomi. Sementara itu, kawasan perdesaan adalah wilayah yang mempunyai kegiatan utama pertanian, termasuk pengelolaan sumber daya alam dengan susunan fungsi kawasan sebagai tempat permukiman perdesaan, pelayanan jasa pemerintahan, pelayanan social, dan kegiatan ekonomi.

\section{A. Pola Penggunaan Lahan Di Kawasan Perkotaan}

Secara teoritis, terdapat 3 (tiga) model pola penggunaan lahan di perkotaan, yaitu Concentric, Sektor, Multiplei Nuclei Concept.

\section{Teori Jalur Sepusat (Concentric Zone Theory)}

Teori ini berawal dari penelitian pembangunan kota Chicago oleh E.W. Burgess pada tahun 1925. Atas dasar kajiannya terhdap struktur kota atau model Konsentris yang disebut juga "Zoning Model". Model ini mencerminkan struktur pertumbuhan spatial dari suatu kota berupa zona - zona yang konsentris. Menurut Burgess, kota Chicago meluas secara merata dari suatu inti asli sehingga tumbuhlah zona - zona yang masing - masing meluas sejajar dengan pentahapan kolonisasi ke arah zona yang letaknya paling luar. Dengan demikian, setiap saat dapat ditemukan sejumlah zona yang letaknya konsentris sehingga strukturnya berbentuk gelang. Dengan asumsi 
keterjangkauan adalah sama untuk segala arah (bentuk lingkaran). Teori ini membagi 5 (lima) zona penggunaan lahan dalam kawasan perkotaan yaitu sebagai berikut:

a. Pada lingkaran dalam terletak pusat kota (central business district atau CBD), yang terdiri atas: bangunan - bangunan kantor, hotel, bank, bioskop, pasar dan toko pusat perbelanjaan.

b. Pada lingkaran tengah pertama terdapat jalur alih yaitu terdiriatas rumah - rumah sewaan, kawasan industry, dan perumahan buruh yang relative sempit/kumuh. Zona ini disebut juga dengan zona peralihan atau transition zone.

c. Pada lingkaran tengah kedua terletak jalur wisma buruh, yakni kawasan perumahan untuk tenaga kerja pabrik. Penduduk zona ini terdiri dari buruh rendahan, banyak yang berasal dari zona peralihan dan migran, serta buruh menengah. Pertimbangan pemilihan lokasi sebagai tempat tinggal adalah karena dekat dengan tempat kerja. Kondisi rumah relative tidak berdempetan lagi. Zona ini disebut juga dengan Zone of Working men's home.

d. Pada lingkaran luar terdapat jalur mdyawisma, yakni kawasan perumahan yang luas untuk tenaga kerja halus dan kaum madya (middle class). Zona ini disebut juga dengan Zone of better residences.

e. Di lingkaran luar terdapat jalur ulang - alik: sepanjang jalan besar terdapat perumahan masyarakat golongan madya dan golongan atas. Zona ini disebut juga dengan Zone of Commuters.

Secara singkat pola penggunaan lahan jalur sepusat ini, dapat dilihat pada Gambar 2.1

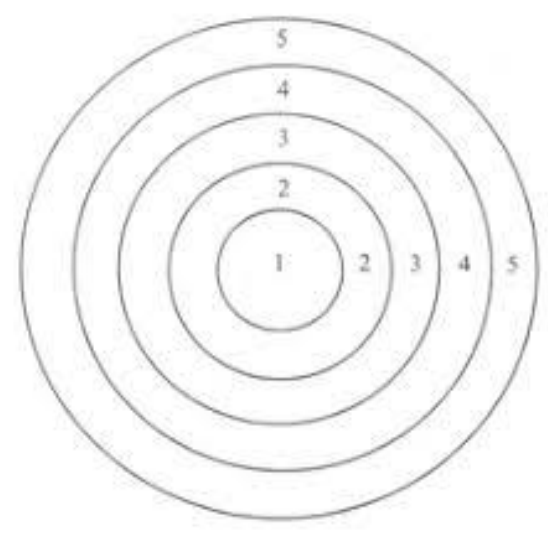

Gambar 2.1 Pola penggunaan Lahan jalur Sepusat (Concentric Zone Theory) 


\section{Teori Sektor (Sector Theory)}

Teori yang dikemukakan oleh Hoer Hoyt (1939) ini merupakan perluasan dari teori zona kosentris dengan pola pembangunan yang tidak merata (irregular). Teori Homer Hoyt tidak bertentangan dengan Burgess, hanya merupakan modifikasi saja. Dalam struktur kota yang sektoral, pertumbuhan kota yang paling pesat terjadi disepanjang jalan utama (arteri) dan pada koridor - koridor kota. Homer Hoyt mengatakan pengelompokan tata guna lahan di kota itu menyebar dari pusat kea rah luar berupa sector (wedges) yang bentuknya menyerupai kue tart. Tata guna lahan di kota mengalir dari pusat ke luar meyerupai bentuk wedges. Konsep yang dikemukakan Homer Hoyt ini menyatakan bahwa kota tersusun sebagai berikut:

a. Pada lingkaran pusat terdapat pusat kota atau CBD

b. Pada sector tertentu terdapat kawasan industry ringan dan kawasan perdagangan

c. Dekat pusat kota dan dekat sekotr tersebut, pada bagian sebelah menyebelahnya terdapat sector murbawisma, yaitu kawasan tempat tinggal kaum murba atau kaum buruh.

d. Agak jauh dari pusat kota dan sector industry serta perdagangan terletak sekotr madyawisma.

e. Lebih jauh lagi terdapat sekotr adiwisma, kawasan tempat tinggal golongan atas. Secara singkat pola penggunaan lahan menurut teori sector, dapat dilihat pada gambar 2.2

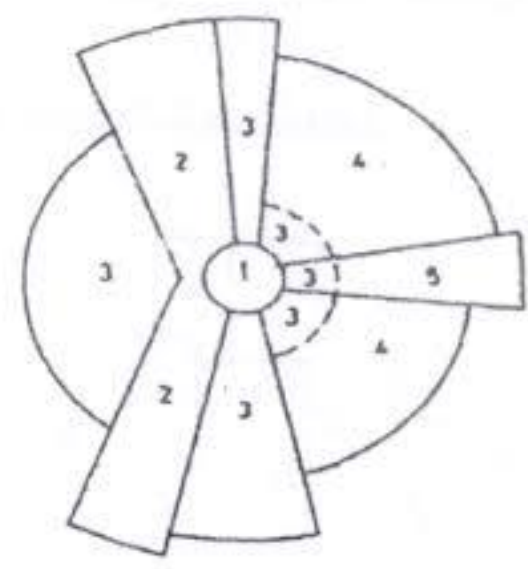

Gambar 2.2 Pola Penggunaan Lahan Sektor 


\section{Teori Pusat Lipat Gamda (Multiplei Nuclei Concept)}

Teori Multiple-Nuclei atau teori Inti Ganda ini dikemukakan oleh C.D Harris dan F.L. Ullman (1945). Teori yang dikemukankan oleh Haris dan Ullman ini menyatakan bahwa kawasan pusat kota tidak dianggap satu - satunya pusat kegiatan atau pusat pertumbuhan tetapi suatu rangkaian pusat kegiatan atau pusat pertumbuhan dengan fungsi yang berlainan seperti industry, rekreasi, perdagangan dan sebagainya. Teori ini umumnya berlaku untuk kota - kota yang agak besar. Menurut teori ini, kota terdiri atas sebagai berikut:

a. Pusat kota atau CBD

b. Kawasan niaga dan industry ringan

c. Kawasan murbawisma, tempat tinggal berkualitas rendah

d. Kawasan madyawisma, tempat tinggal berkualitas menengah

e. Kawasan adiwisma, tempat tinggal berkualitas tinggi

f. Pusat industry berat

g. Pusat niaga/perbelanjaan lain di pinggiran adiwisma

h. Upakota, untuk kawasan madyawisma dan adiwisma.

i. Upakota (suburb) untuk kawasan industry

Secara singkat pola penggunaan lahan menurut teori pusat lipat ganda ini dapat dilihat pada gambar 2.3

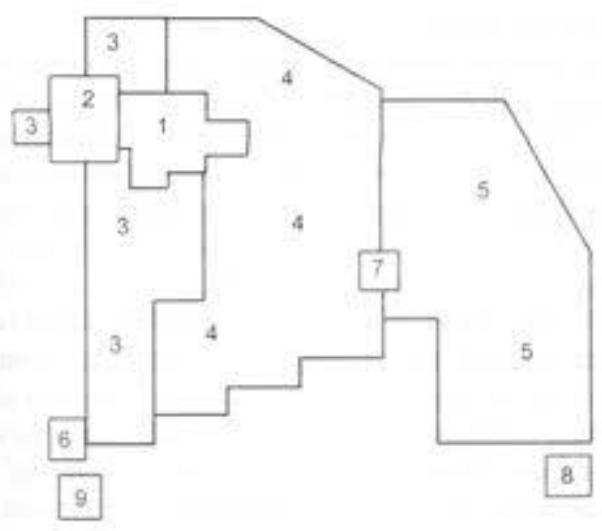

Gambar 2.3 Pola penggunaan lahan Pusat Lipat Ganda

Dari ketiga teori di atas, tmapk bahwa keberadaan kawaan murbawisma (tempat tinggal berkualitas rendah/ tempat tinggal buruh) selalu berdekatan dengan pusat kota. Hal ini disebabkan aspek biaya transportasi yang mejadi pertimbangan buruh untuk memilih 
tempat tiggal berdekatan dengan lokasi tempat bekerjanya. Sedangkan keberadaan kawasan adiwisma (perumahan bagi middle-class ke atas) lebih memilih lokasi yang nyaman menjauh dari pusat kota. Dari fenomena di atas, dapat diindikasikan bahwa factor ekonomi menjadi bahan pertimbangan utama dalam pemilihan lokasi penggunaan lahan di perkotaan.

Perbedaan antara model ke -3 (multiplei Nuclei) dan kedua model lainnya (Concentric dan Sector Model) terletak pada banyaknya 'inti' yang terdapat pada suatu kota. Jika pada model 1 dan 2, suatu kota hanya memiliki sebuah 'inti', maka pada model penggunaan lahan ke 3, suatu kota dapat dijumpai beberapa 'inti'.

\section{B. Pola Penggunaan Lahan di Kawasan Perdesaan}

Penggunaan lahan di pedesaan terbagi menjdai 2 (dua) yaitu penggunaan lahan bagi kehidupan social dan penggunaan lahan bagi kehidupan ekonomi. Penggunaan lahan bagi kehidupan social, seperti berkeluarga, bersekolah, beribadah, berolahraga dan sebagainya. Sedangkan, kegiatan ekonomi seperti bertai, berkebun, berternak, memelihara/menangkap ikan, menebang kayu, dan sebagainya. Jadi penggunaan lahan di wilayah perdesaan adalah untuk pekampungan dalam rangka kegiatan social dan untuk pertanian dalam rangka kegiatan ekonomi (Jayadinata, 1999).

Bentuk perkampungan atau permukiman di perdesaan terbagia menjadi 2 (dua) macam yaitu Permukiman memusat (aglomerated rural settlement) dan Permukiman terpencar (disseminated rural settlement). Pemukiman memusat, rumahnya mengelompok, terdiri atas sekitar 40 unit rumah. Di sekitar kampung terdapat tanah bagi pertanian, perikanan, peternakan dan lain - lain, tempat dimana pendudukbekerja sehari - hari mencari nafkah. Dalam perkembangannya, suatu kampung dapat mencapai berbagai bentuk, tergantung pada keadaan fisik dan social. Bentuk perkampungan pertanian umumnya mendekati bentuk bujur sangkar sedangkan perkampungan nelayan umumnya memanjang (satu baris atau beberapa baris rumah) sepanjang pantai atau sepanjang sungai.

Permukiman terpencar, rumahnya terpencar menyendiri, banyak terdapat di Negara Eropa Barat, Amerika, Kanda, Australia dan lain - lain. Perkampungan terpencar di Negara Negara tersebut terdiri atas farmstead, yatu sebuah rumah yang terpencil tetapi lengkap dengan gudang, alat mesin, penggilingan gandum, lumbung dan kandang ternak (Jayadinata, 1999). 

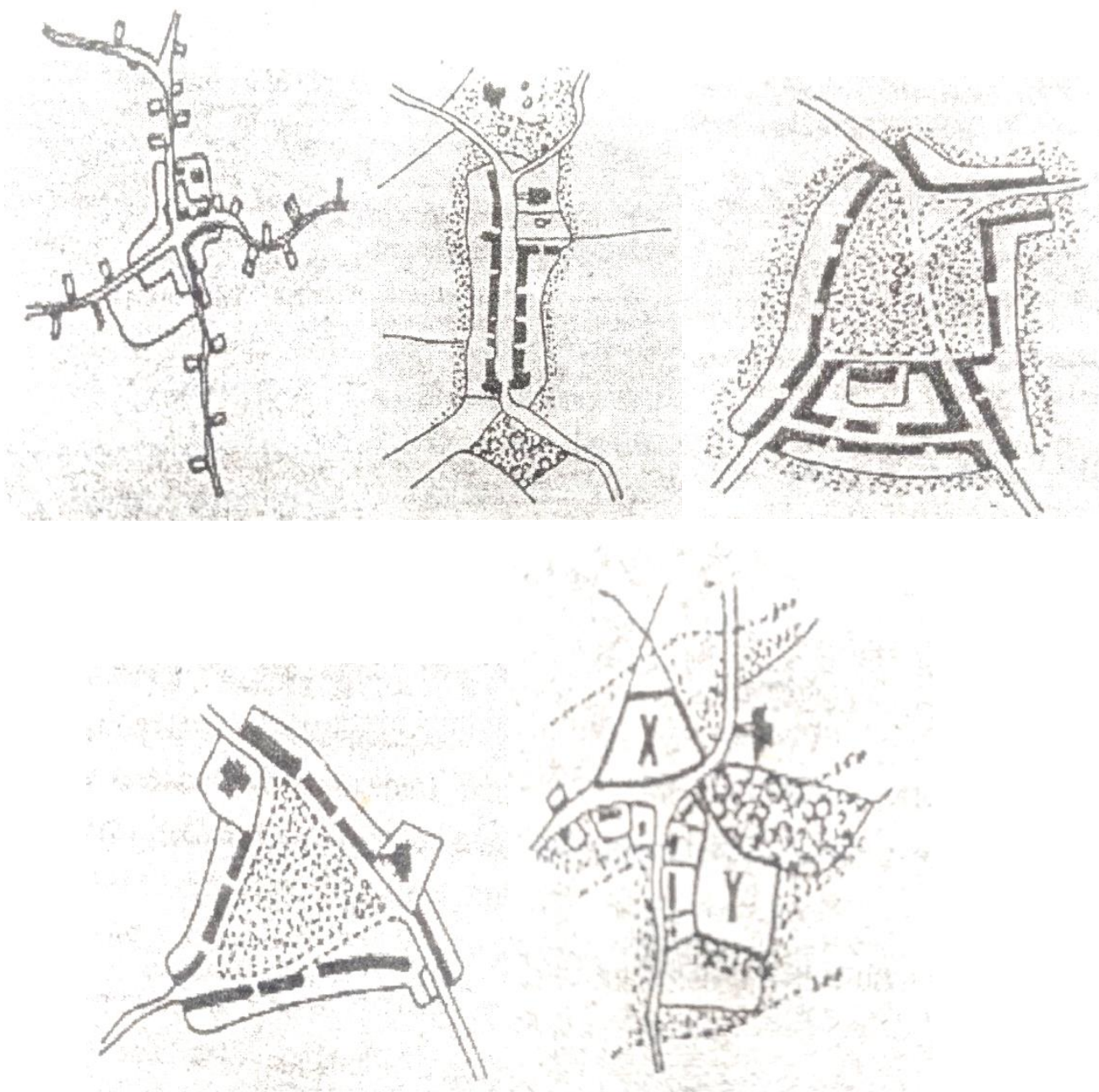

Gambar 2.4 Perkembangan Kampung

Keterangan:

1. Kampung persimpangan jalan

2. Kampung sepanjnang sebuah jalan

3. Kampung bujur sangkar

4. Kampung di belokan jalan

5. Pengembangan kampung, sebaiknya sekolah yang direncanakan jangan dibangun di y tetapi di $\mathrm{X}$ supaya kampung dapat berkembanga dengan seimbang. 
Kesesuaian lokasi kawasan pertanian relative banyak bergantung pada factor fisik alamiah, antara lain iklim (kelembaban dan curah hujan), sifat fisik tanah, tekstur tanah, kelerengan dan lain sebagainya.

\section{DAFTAR PUSTAKA}

Jayadinata, J. T. (1986). Tata guna tanah dalam perencanaan pedesaan, perkotaan dan wilayah. Penerbit Itb.

Kaiser, E. J., Godschalk, D. R., \& Chapin, F. S. (1995). Urban land use planning (Vol. 4). Urbana: University of Illinois press.

Koestoer, R. H. (1997). Perspektif lingkungan desa-kota: teori dan kasus. Penerbit Universitas Indonesia.

Sitawati, Anita. (2016). Materi Pokok Tata Guna dan Pengembangan Lahan. Tangerang Selatan : Universitas Terbuka.

Yusran, A. (2006). Kajian Perubahan Tata Guna Lahan pada Pusat Kota Cilegon (Doctoral dissertation, Program Pascasarjana Universitas Diponegoro). 